\title{
ОСНОВНІ ЗАСАДИ ФОРМУВАННЯ МІСІЇ ПІДПРИЕМСТВ ПОЛІГРАФІЧНОЇ ПРОМИСЛОВОСТІ
}

( І. Б. Шевченко, к.е.н., доцент, НТУУ «КПІ». Київ, Україна

Рассмотрено основные теоретические основы формирования миссии организации, исследовано ее экономическую сущность, место в системе менеджмента предприятия, основные критерии ее формирования и содержание. На основании исследования сформировано миссию полиграфических предприятий и ее роль в определении путей стратегического развития.

The main theoretical foundations for mission of organization is considered in the article. The economic substance, the position in the system of enterprise management, the content, the main

criteria for mission for forming are studied. Based on the research the mission of printing company and its role in strategic development areas is formulated.

Постановка проблеми

Сучасні динамічні темпи розвитку ринку визначають необхідність змін в організаціях. На підприємство як відкриту систему діє велике розмаїття зовнішніх та внутрішніх факторів, що тиснуть на організацію і змушують її змінюватись. Зміни в організації - це спосіб пристосування до мінливих умов середовища та зберегти стабільність її розвитку. Усвідомлення цього факту та керування процесом змін не дозволить протікати процесу некерованих змін, що легко переростають у кризові ситуації із значними матеріальними фінансовими матеріальними втратами.

Тому в сучасних умовах стратегічний менеджмент займає важливе місце у системі управління діяльністю підприємства. За допомогою інструментів стратегічного управління можна впорядкувати господарську діяльність, зменшити ступінь хаотичності роботи підприємства та на порядок підвищити ефективність діяльності.

Одним із таких інструментів $€$ місія підприємства, що включає основоположні цілі та цінності підприємства. Стратегії розвитку можуть змінюватись, організація бізнесу пристосовуватись до мінливих умов діяльності, продукти і товари вдосконалюватись, і тільки вірність базовим корпоративним цінностям у поєднанні із гнучкістю та використанням інновацій пояснюють ефективну довготривалу діяльність більшості відомих корпорацій. 


\section{Аналіз попередніх}

\section{досліджень}

Проблеми стратегічного менеджменту досліджували як зарубіжні, так і вітчизняні науковці: І. Адізес, І. Ансофф, І. О. Бланк, В. В. Ковальов, Д. Коттер, А. Мескон, А. А. Томпсон і А. Дж. Стрікленд, Г. І. Кіндрацька, Н. Н. Треньов, Р. А. Фатхутдінов, З. Є. Шершньова та інші. Загалом науковці і практики визнають важливість та значимість місії організації як основної ідеологеми, що цілеспрямовує розвиток підприємства як соціально-економічної системи. Проте єдиного визначення місії на сьогодні не існує, як i реального практичного інструментарію щодо ії формулювання і принципів розробки.

\section{Мета роботи}

Мета статті - провести дослідження теоретичних засад формування місії підприємства та окреслити основні складові місії вітчизняних поліграфічних підприємств.

\section{Результати проведених досліджень}

Система стратегічного менеджменту на підприємстві складається із елементів, злагоджена взаємодія котрих дозволяє розробляти та реалізовувати ефективні стратегії. Єдиного визначення цих елементів на даний момент не існує, та найчастіше виділяють наступні:

- стратегія, як сукупність управлінських рішень щодо перспективного її розвитку;

- відповідна структура управління, зорієнтована на розроблення і впровадження стратегії;
- організаційна культура [1, C. 26].

Організаційна структура окреслює межі підрозділів і встановлює формальні зв'язки між ними, а організаційна культура - виробляє правила гри в колективі, підтримує стратегію, забезпечує відкритість до нових ідей. В результаті утворюється трикутник: «стратегія розвитку-організаційна структураорганізаційна культура», який має бути внутрішньо стійким і перебувати в гармонії зі зовнішнім середовищем.

Це завдання і покликана виконати місія підприємства ефективно взаємопоєднати всі елементи стратегічного менеджменту. Місія $€$ елементом організаційної культури підприємства. При цьому вона сприяє:

- згуртуванню працівників організації, усвідомленню ними значущості своєї діяльності, підсилює ентузіазм працівників найефективніше використовувати свої фахові уміння, досвід, фізичні та інтелектуальні можливості в роботі;

- формує імідж організації, сприяє створенню позитивного образу організації у споживачів, постачальників, ділових партнерів, тощо;

- дозволяє розробити та взаємно узгодити стратегічне бачення компанії, довгострокові цілі та програми дій, направлених на їх досягнення - взаємопов'язує організаційну культуру та систему стратегічного планування;

- декларуючи певні принципи діяльності, впливає на систему та методи управління, що обираються топ-менеджментом; 
- дозволяє полегшити

сприйняття нововведень в організації, своєчасно проводити реструктуризацію компанії, зменшує опір змінам взаємозв'язок із організаційною структурою організації.

В сучасних наукових дослідженнях немає єдиного визна- чення терміну «місія». Деякі визначення були систематизовані у табл. 1.

Як бачимо, існує досить значна розбіжність у наукових поглядах: це і цільова функція, сенс існування, призначення організації, філософія компанії, документ, зовнішнього ринкового чи внутрішнього соціального

Таблиця 1

Визначення терміну «місія» різними науковцями

\begin{tabular}{|c|c|}
\hline Автор & Визначення \\
\hline Зуб А. Т. [2] & $\begin{array}{l}\text { основна загальна мета організації, чітко виражена при- } \\
\text { чина її існування, її призначення. Формулюється, насам- } \\
\text { перед, з погляду підвищення соціальної ролі організації. } \\
\text { Корпоративна місія (господарська місія, концепція } \\
\text { бізнесу) характеризує можливість займатися бізнесом, } \\
\text { на який фірма орієнтується з урахуванням ринкових по- } \\
\text { треб, характеру споживачів, особливостей продукції й } \\
\text { наявності конкурентних переваг. Концепція корпоратив- } \\
\text { ної місії - надійний елемент ідеологічної бази форму- } \\
\text { вання організації. }\end{array}$ \\
\hline Виханский О. С. [3] & $\begin{array}{l}\text { Місія - це філософія й призначення, сенс існування } \\
\text { організації. Це сформульоване затвердження щодо того, } \\
\text { для чого або з якої причини існує організація, тобто місія } \\
\text { розуміється як твердження, що розкриває сенс існування } \\
\text { організації, у якому проявляється відмінність даної } \\
\text { організації від їй подібних. }\end{array}$ \\
\hline Саєнко М. Г. [4] & $\begin{array}{l}\text { найбільш загальні орієнтири функціонування підприємс- } \\
\text { тва, як правило, зовнішнього спрямування, що відобра- } \\
\text { жають зміст його існування, його філософію, бачення } \\
\text { свого місця в даному бізнесі, в регіоні, в суспільстві. }\end{array}$ \\
\hline $\begin{array}{c}\text { Шершньова 3. } € . \\
{[5]}\end{array}$ & $\begin{array}{l}\text { мета, задля якої існує організація. Місія тісно пов'язана з } \\
\text { такими категоріями, як «бачення» розвитку фірми, «філо- } \\
\text { софія існування фірми» тощо, і майже завжди є особис- } \\
\text { тим поглядом керівників найвищого рівня на перспективу } \\
\text { розвитку підприємства. }\end{array}$ \\
\hline Осовська Г. В. [6] & $\begin{array}{l}\text { Цільова функція починається із встановлення загальної } \\
\text { мети підприємства, яка показує причину його існування. } \\
\text { В літературі вона позначається такими поняттями, як } \\
\text { «політика», «філософія», «місія». В ній деталізується ста- } \\
\text { тус підприємства, декларуються принципи його роботи, } \\
\text { заяви і справжні наміри керівництва, дається визначення } \\
\text { найважливіших характеристик організації. }\end{array}$ \\
\hline Македон В.В.[7] & $\begin{array}{l}\text { основоположний документ, в якому підприємство описує } \\
\text { сферу (вид або галузь) своєї підприємницької (комерцій- } \\
\text { ної) діяльності, визначає цільовий ринок (або його сег- } \\
\text { мент), висловлює свої керівні принципи і встановлює пе- } \\
\text { рспективні цілі стосовно досягнення бажаних числових } \\
\text { оцінок економічних, фінансових, соціальних і екологічних } \\
\text { показників, а також проголошує свою систему суспільних } \\
\text { і загальнолюдських цінностей. }\end{array}$ \\
\hline
\end{tabular}




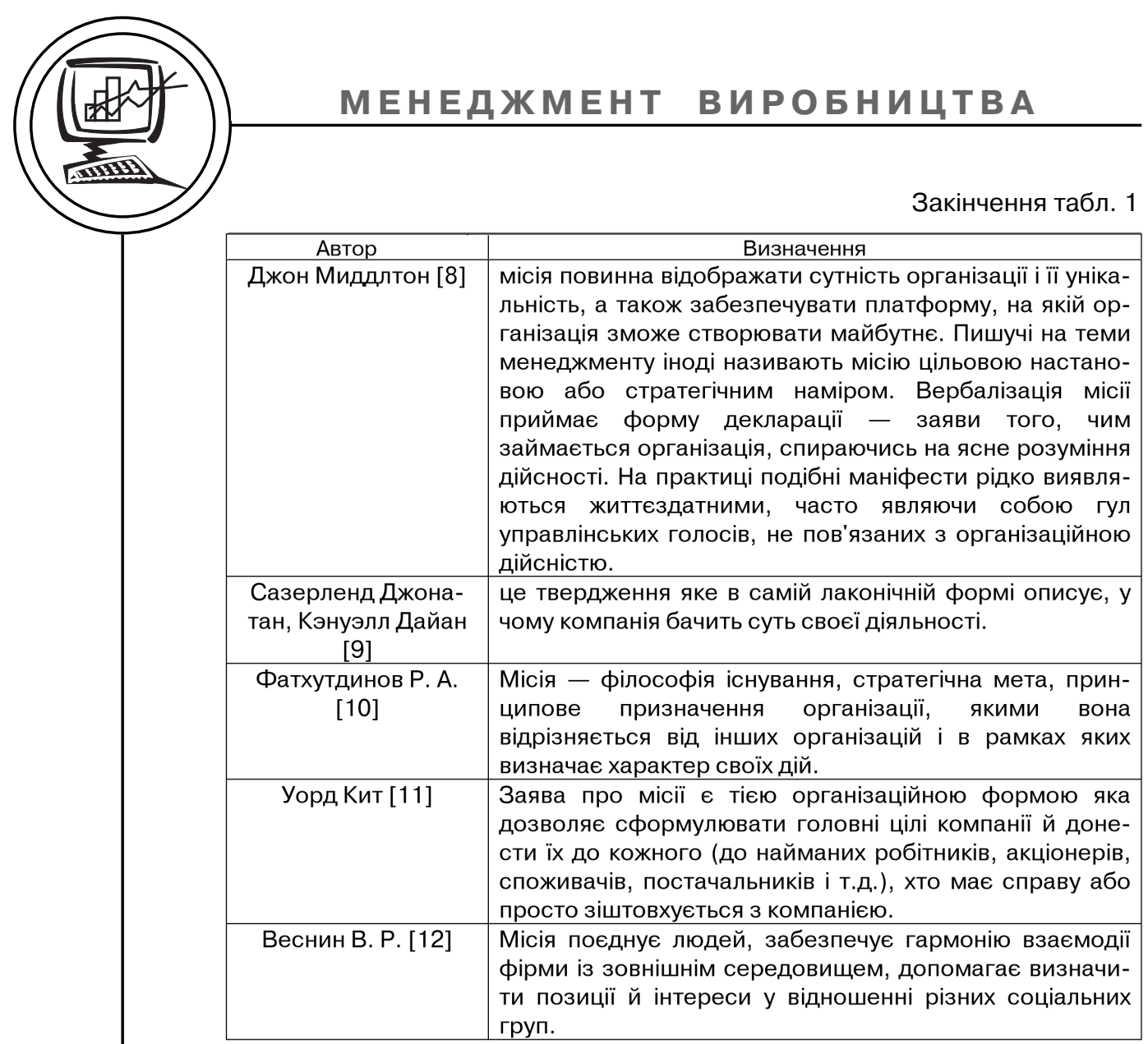

спрямування. Проте більшість розділяють основну думку, що місія виражає основне призначення організації та є частиною філософії компанії. Пропонуємо наступне трактування:

Місія - це ключовий елемент базової ідеології організації, що включає основні цінності компанії та розкриває зміст її існування, її основне призначення.

Як ключовий елемент базової ідеології та частина філософії компанії, місія повинна включати в себе фундаментальні принципи і основи існування організації, що їх можна сформувати за допомогою ключових цінностей компанії. Вони повинні залишатися стабільними і незмінними. Тому не можуть бути направлені ні на зовнішнє середовище, що в сучасних умовах надзвичайно динамічно розвивається; ні на споживача, в якого змінюються потреби або в компанії може змінитися споживчий сегмент; ні на майбутнє бачення компанії. Не можуть вони орієнтуватися на персонал, скоріше, навпаки, дана система цінностей слугує для того, щоб об'єднувати однодумців, що не тільки цікавляться економічними та вартісними показниками, але і прагнуть створити дещо більше. Філософія компанії слугує для того, щоб представити компанію зовнішньому оточенню, показати свою унікальність та відмінність від інших, сформувати певний 
імідж підприємства. Місія також не може формуватись на основі майбутнього бачення організації, тому що топ-менеджмент у сучасній і майбутній діяльності повинен керуватися однією і тією ж системою ключових цінностей.

Для того, щоб перелік ключових цінностей не перетворився у декларації, формально виражені на папері виражені в документарній формі, «являючи собою гул управлінських голосів, не пов'язаних з організаційною дійсністю» (Джон Міддлтон) потрібно, щоб дані ключові цінності були щирими переконаннями тих осіб, що представляють організацію та не зважаючи на комерційну вигоду компанія залишиться їм вірними та продовжуватиме ї поділяти. Окрім того, досить часто трапляються ситуації, коли місія розроблена, а персонал не ознайомлений із нею, із системою тих філософських ідеологем, якими керується компанія. Тому повинна вестись постійна робота із пропаганди місії серед персоналу організації. Це дозволить згуртувати колектив, відчути себе частиною єдиного цілого, що працює на благо суспільства.

Основне призначення, сенс існування організації часто плутають із конкретними бізнесстратегіями або починають перераховувати свої товари чи послуги. Приклади місій великих успішних компаній це спростовують. Вони чітко розмежовують незмінні філософські цінності та елементи, що можна і необхідно вдосконалювати (табл. 2).

Отже, основною характеристикою місії повинна бути її незмінність та актуальність протягом всього циклу існування організації. Досить багато компаній, при формулюванні місії, зосереджуються на товарах чи послугах, базових технологіях чи споживчих сегментах. Багато

Таблиця 2

Приклади успішних та неприйнятних місій організацій

\begin{tabular}{|c|c|c|}
\hline Організація & Призначення & $\begin{array}{c}\text { Невірне формулювання } \\
\text { призначення }\end{array}$ \\
\hline Hewlett-Packard & $\begin{array}{c}\text { Сприяти технічному прогресу } \\
\text { заради розвитку та про- } \\
\text { цвітанню людства }\end{array}$ & $\begin{array}{c}\text { Виробляти найкращу } \\
\text { офісну техніку }\end{array}$ \\
\hline Walt Disney & Робити людей щасливими & $\begin{array}{c}\text { Займатись } \\
\text { мультиплікацією }\end{array}$ \\
\hline Nike & $\begin{array}{c}\text { Пізнати дух конкуренції, } \\
\text { смак перемоги і радість } \\
\text { святкування над суперниками }\end{array}$ & $\begin{array}{c}\text { Створювати найкраще } \\
\text { спортивне обладнання } \\
\text { та одяг }\end{array}$ \\
\hline $\begin{array}{c}\text { Wal-Mart (мережа } \\
\text { супермаркетів) }\end{array}$ & $\begin{array}{c}\text { Дати звичайним людям } \\
\text { можливість купувати ті } \\
\text { товари, котрі могли собі } \\
\text { раніше дозволити лише люди } \\
\text { з достатком } \\
\end{array}$ & $\begin{array}{c}\text { Надавати найкращі } \\
\text { торговельні послуги } \\
\text { та якісно обслуговувати } \\
\text { клієнтів }\end{array}$ \\
\hline Sony & $\begin{array}{c}\text { Відчувати радість від техно- } \\
\text { логічних відкриттів та їх } \\
\text { використання на благо } \\
\text { суспільства }\end{array}$ & $\begin{array}{c}\text { Виробляти найкращу } \\
\text { електронну техніку }\end{array}$ \\
\hline
\end{tabular}


науковці стверджують, що місія повинна бути направлена на споживача та зовнішнє середовище. Проте товари і технології змінюються; в зовнішньому середовищі починають діяти нові чинники, впливаючи на діяльність фірми; не існує постійних вподобань та пріоритетних вимог споживачів. Основне призначення організації не тільки у створенні певного продукту чи отриманні прибутку. Люди об'єднуються, щоб досягнути того, що окремо людина зробити не в силах, внести свій вклад в життя суспільства та створити те, що представляє цінність. Успіх роботи компанії залежить від ефективної самовіддачі її працівників, а це неможливо без ї достатньо лояльного відношення, коли працівники зберігають відданість компанії навіть за несприятливих економічних обставин. Тільки діюча ідеологія компанії, котра щиро переконана і дотримується своїх ключових цінностей та призначення, та вміє переконати у істинності своєї місії інших - зможе об'єднати, мотивувати та утримати талановитих спеціалістів.

При створенні місії організації необхідно дотримуватись певних принципів. Для того, щоб місія не перетворилась на формальний документ доцільно використати правила, сформульовані Шершньовою 3. Є. [5]:

Правило 1. Забезпечити відкриту розробку та обговорення мети серед співробітників та інших зацікавлених у діяльності підприємства осіб (за допомогою формальних процедур, що дає змогу компенсувати наслідки змін у складі співробітників і враховувати альтернативи в ході формулювання та коригування мети).

Правило 2. Встановити, оцінити та обговорити альтернативні варіанти мети в межах організації (що допомагає співробітникам усвідомити, чим $€$ насправді організація, де вони працюють).

Правило 3. Визначити в процесі обговорення прихильників і супротивників. Перші об'єднуються навколо мети, інші усвідомлюють, що їхні джерела економічного та морального задоволення перебувають за межами цієї організації, і приймають рішення про звільнення.

Враховуючи викладене вище, можна сформулювати принципи формування місії:

- повинна містити ключові цінності та призначення компанії;

- як частина філософії компанії повинна надихати та згуртовувати людей;

- поділятися більшою частиною колективу організації;

- містити щирі переконання, що не змінюються з часом та не залежать від комерційної вигоди;

- формувати унікальний образ компанії;

- участь у розробці місії повинні брати більшість трудового колективу підприємства;

- мотивувати працівників до виконання поставлених завдань та досягнення визначених цілей, а також інших цільових груп до співпраці з нею;

- визначати загальна корисність організації для суспільства тощо.

Аналізуючи діяльність підприємств поліграфії, видавничої 
справи та книго розповсюдження, можна спрогнозувати з великою долею ймовірності кризу даної галузі. Про це свідчать певні тенденції ринку книжкової та поліграфічної продукції, а саме:

- Зменшення у 2011 кількості тиражів та кількості найменувань книжкової продукції [13];

- На сьогодні в Україні друкується менше 1 книжки на душу населення, включаючи підручники;

- Більше 80 \% ринку заповнено продукцією російського виробництва [13];

- Поліграфія є імпортозалежною галуззю як щодо поліграфічного обладнання, так і розхідних матеріалів;

- Зростає криза неплатежів за реалізовану друковану продукцію;

- Спостерігається недостатність державного фінансування. У 2011 році навіть ті кошти, що були заплановані бюджетом, не надійшли у повному обсязі.

I це далеко не повний перелік проблем. Керівники підприємств, діючи в сучасних умовах, на виживання підприємств, на вирішення сьогочасних проблем, котрі не дадуть бажаних результатів без усвідомлення стратегічних цілей та розробки стратегії. Це надасть можливість цілесрямувати зусилля у єдиному напрямі розвитку і значно підвищити результативність діяльності. Наростання кризових симптомів повинно привести до усвідомлення необхідності реорганізаційних змін у галузі та управлінні. Організація та реалізація цих змін $€$ основним завданням саме стратегічного менеджменту.

Отже, 3 вищезазначеного можна зробити висновки, що настає життєва необхідність проведення змін на підприємствах поліграфічної галузі. Для того, щоб зміни були ефективними, необхідно створити систему стратегічного менеджменту і підвищити їі дієвість за допомогою чітко сформульованої місії. Вона забезпечить розробку стратегії необхідних нововведень, здійснить пропаганду необхідності змін, сприятиме зменшенню опору змінам серед трудового колективу.

В основному, підприємства поліграфії, видавничої справи працюють на замовлення, тому вважаємо, що основні ключові цінності повинні в першу чергу спрямовані на споживача. Особливості продукції потребують нестандартного підходу до кожного замовлення, тому необхідно заохочувати персонал до нестандартних креативних рішень. Значну долю у виробництві поліграфічних підприємств займає книжкова продукція, основне призначення якої допомагати пізнавати світ, навчатися, знайомити із історією і культурою, сприяти популяризації рідної мови. Тому в перелік основних ключових цінностей пропонуємо включити:

- Підвищувати імідж української культури, сприяти духовному та інтелектуальному зростанню людей;

- 3 повагою та увагою ставитись до кожного замовника, забезпечуючи високу якість та швидкість виконання замовлення; 
- Надавати працівникам можливість реалізувати свій творчий потенціал;

- Соціальна відповідальність бізнесу.

Щоб визначитися із призначенням підприємств поліграфії, необхідно відповісти на запитання: навіщо потрібна їх продукція? Поліграфічну продукцію можна поділити на чотири основні групи: пакувальні матеріали, рекламна продукція, книжки, газети і журнали. Вона допомагає впізнати серед великої кількості товарів пакування улюбленого виробника, рекламна продукція інформує споживачів про виробників та види їх продукції, формує імідж компанії, допомагає зробити ближчими виробника та споживача. Книжки, газети та журнали виконують інформативну, пізнавальну та розважальну функції. Тому призначення підприємств поліграфічної промисловості можна визначити наступним чином: «Ми допомагаємо зробити світ барвистим і кольоровим, підвищити інформованість та інтелектуальний рівень людей».

Використовуючи систему ключових цінностей та призначення можна сформувати як приклад наступну місію:

«Ми допомагаємо зробити світ барвистим і кольоровим, підвищити інформованість та інтелектуальний рівень людей. Наша продукція сприяє підвищенню іміджу країни, духовному та культурному зростанню людей. Ми з повагою та увагою ставимось до кожного замовника, забезпечуючи високу якість та швидкість виконання замовлення. Наші працівники мають змогу реалізувати свій творчий потенціал, а ми сприяємо цьому та заохочуємо. Ми несемо соціальну відповідальність за ведення свого бізнесу, сприяємо економічному зростанню країни, забезпечуючи високу прибутковість підприємства, захищаючи інтереси власників, створюючи нові робочі місця, забезпечуючи працівників гідною заробітною платою».

Звичайно, дана місія це лише приклад, підґрунтя, на якому кожне підприємство може сформувати свою місію, виділивши свою унікальність та особливість.

\section{Висновки}

1. Для підвищення ефективності стратегічного менеджменту кожне підприємство повинно сформулювати місію.

2. Визначено термін «місія організації».

3. Місія повинна включати систему ключових цінностей та призначення організації, презентувати її зовнішньому середовищу, підкреслювати ії унікальність та покращувати імідж.

4. Кризові явища, що спостерігаються у поліграфічній галузі, спонукають підприємства до запровадження системи стратегічного менеджменту, одним із інструментів якого $€$ місія організації.

5. Сформульовано місію поліграфічних підприємств, що може бути використано у практичній діяльності як приклад, основа.

3 метою подальшого удосконалення системи стра- 
тегічного менеджменту на підприємствах, доцільно розробити практичні рекомендації для розробки та формулювання місії, а також розвивати і вдосконалювати інший інструментарій стратегічного менеджменту.

1. Кіндрацька Г. І. Стратегічний менеджмент : Навч. Посібник / Г. І. Кіндрацька. - К. : Знання, 2006. - 366 с. 2. Зуб А. Т. Стратегический менеджмент : Теория и практика : Учебное пособие для вузов / А. Т. Зуб. М. : Аспект Пресс, 2002. - 415 с. 3. Виханский О. С. Стратегическое управление : Учебник. - 2-е изд., перераб. и доп. / О. С. Виханский. - М. : Гардарика, 1998. - 296 с. 4. Саєнко М. Г. Підручник / М. Г. Саєнко. - Тернопіль : «Економічна думка». - 2006. - 390 с. 5. Шершньова 3. Є. Стратегічне управління : Підручник. - 2-ге вид., перероб. і доп. / 3. Є. Шершньова. - К. : КНЕУ, 2004. - 669 с. 6. Осовська Г. В. Основи менеджменту : Навч. посібник, для студентів вищих навчальних закладів / Г. В. Осовська. К. : «Кондор», 2003. - 556 с. 7. В. В. Македон. Бізнес-планування : Навч. пос. / В. В. Македон. - К. : Центр учбової літератури, 2009. - 236 с. 8. Джон Миддлтон. Библиотека избранных трудов о стратегии бизнеса. Пятьдесят наиболее влиятельных идей всех времен / Пер. с англ. - М. : ЗАО «Олимп-Бизнес», 2006. - 272 с. 9. С. Джонатан, К. Дайан. Стратегический менеджмент Ключевые понягия / Пер. с англ., Под ред. Е. Е. Козлова. - Днепропетровск Баланс Бизнес Букс, 2005. - 440 с. 10. Фатхутдинов Р. А. Стратегический менеджмент : Учебник. - 7-е изд., испр. и доп. / Р. А. Фатхутдинов. - М. : Дело, 2005. - 448 с. 11. У. Кит. Стратегический управленческий учет / Пер. с англ. - М. : ЗАО «Олимп-Бизнес», 2002. 448 с. : ил. 12. Веснин В. Р. Стратегическое управление : Учебник / В. Р. Веснин. - М. : ТК Велби, Изд-во Проспект, 2004. - 328 с. 13. Випуск видавничої продукції в Україні / Державна наукова установа «Книжкова палата України імені Івана Федорова» [Електронний ресурс] : Режим доступу : http://www.ukrbook.net/].

1. Kindrats'ka H. I. Stratehichnij menedzhment : Navch. posibnik / H. I. Kindrats'ka. - K. : Znannja, 2006. - 366 s. 2. Zub A. T. Stratehicheskij menedzhment: Teorija i praktika : Uchebnoje posobije dlja vuzov / A. T. Zub. M. : Aspekt Press, 2002. - 415 s. 3. Vihanskij O. S. Stratehicheskoje upravlenije : Uchebnik. - 2-e izd., pererab. i dop. / O. S. Vihanskij. - M. : Hardarika, 1998. - 296 s. 4. Sajenko M. H. Pidruchnik / M. H. Sajenko. - Ternopil' : «Ekonomichna dumka». - 2006. - 390 s. 5. Shershn'jova Z. Je. Stratehichne upravlinnja : Pidruchnik. - 2-he vid., pererob. i dop. / Z. Je. Shershn'jova. - K. : KNEJU, 2004. - 669 s. 6. Osovs'ka H. V. Osnovi menedzhmentu : Navch. posibnik, dlja studentiv vishchih navchal'nikh zakladiv / H. V. Osovs'ka. - K. : «Kondor», 2003. - 556 s. 7. V. V. Makedon. Biznes-planuvannja : Navch. pos. / V. V. Makedon. - K. : Tsentr uchbovoji literaturi, 2009. - 236 s. 8. Jon Middlton. Biblioteka izbrannjikh trudov o stratehii biznesa. Pjatdesjat naiboleje vlijatel'nikh idej vseh vremjen / Per. s anhl. - M. : ZAO «Olimp-Biznes», 2006. - 272 s. 9. S. Dzhonatan, K. Dajan. Stratehicheskij menedzhment. Kljuchevije ponjatija / Per. s anhl., pod red. E. E. Kozlova. - Dnepropetrovsk : Balans Biznes Buks, 2005. - 440 s. 10. Fathutdinov R. A. Stratehicheskij menedzhment : 
Uchebnik. - 7-e izd., ispr. i dop. / R. A. Fathutdinov. - M. : Delo, 2005. 448 s. 11. U. Kit. Stratehicheskij upravlenchenskij uchjet / Per. s anhl. - M. : ZAO «Olimp-Biznes», 2002. - 448 s. : il. 12. Vesnin V. R. Stratehicheskoje upravlenije : Uchebnik / V. R. Vesnin. - M. : TK Velbi, Izd-vo «Prospect», 2004. - 328 s. 13. Vjipusk vjidavnichoji produktsiji v Ukrajini / Derzhavna naukova ustanova «Knizhkova palata Ukrajini imeni Ivana Fedorova» [Elektronnij resurs] : Rezhim dostupu : http://www.ukrbook.net/].

Рецензент - А. В. Кваско, к.е.н., доцент, НТУУ «КПI»

Надійшла до редакції 17.05.12 